International Research Journal of Microbiology (IRJM) (ISSN: 2141-5463) Vol. 7(1) pp. 010-017, February, 2018

Available online http://www.interesjournals.org/IRJM

DOI: http:/dx.doi.org/10.14303/irjm.2018.016

Copyright (@ 2018 International Research Journals

Full Length Research Paper

\title{
Mass Survey of Human African Trypanosomiasis in Ukwani and Ethiope East Local Government Areas, Delta State, Nigeria
}

\author{
${ }^{* 1}$ Musa D., ${ }^{1}$ Fajinmi A. O., ${ }^{1}$ Abdullahi R., ${ }^{1}$ Irhue A. E., ${ }^{1}$ Toma I. M., ${ }^{1}$ Sambo F., ${ }^{1}$ Kugama M. A., \\ ${ }^{1}$ Kassim M.A., ${ }^{1}$ Ormaga M. T., ${ }^{1}$ Enwezor F. N. C., ${ }^{1}$ Kalejaiye J. O., ${ }^{1}$ Dede P. M., ${ }^{1}$ Mamman M., \\ ${ }^{2}$ Anagbogu I., and ${ }^{3}$ Cephas $\mathrm{E}$.
}

${ }^{1}$ Nigerian Institute for Trypanosomiasis and Onchocerciais Research (NITR) Kaduna, Nigeria

${ }^{2}$ Federal Ministry of Health $(\mathrm{FMoH})$

${ }^{3}$ World Health Organization (W.H.O)

${ }^{*}$ Corresponding e-mail: musakaus78@gmail.com

\begin{abstract}
This study was intended to update the epidemiological status of Human African Trypanosomiasis (HAT), also known as sleeping sickness in Ukwuani and Ethope East Local Government Areas (LGAs) Delta State, Nigeria, and to establish a HAT control programme. In 2012, 1979 people from 26 villages were serologically screened for Trypanosomabruceigambiense, the causative agent of HAT. In 2012, surveys were carried out in villages where HAT cases had been identified. 119individuals were screened using the card agglutination Trypanosomiasis test (CATT), and then parasitologically examined for the presence of the parasite. CATT- positive individuals in whom the presence of the parasite could not be confirmed were further tested with the CATT using serum dilutions, and those with a positive antibody titer of $1-$ in - 4or above were followed-up. Patients with 10 white cells and no trypanosomes in their cerebrospinal fluid (CSF) were classified as being in the second stage of the disease. Vector control was also considered necessary.In this survey, of the 1979 people screened, consisting of $7(0.57 \%)$ out of 1220 females and $4(0.53 \%)$ out of 759 males with no difference in sex specificincidences. The positive cases occurred in Umutu and Umuebu communities in Ukuwani LGA, and in Ovu and Okpara inland communities in Ethiope- East LGA.
\end{abstract}

Keywords: Trypanosomiasis, African, Epidemiology, Diagnosis; CATT, HAT, PATTEC, NITR.

\section{INTRODUCTION}

Human African Trypanosomiasis or Sleeping Sickness (WHO 2014) is a parasiticdisease of humans and other animals. It is caused by protozoa of the species Trypanosomabrucei Kennedy,et al., (2013). There are two types that infect humans, Trypanosomabrucei gambiense (T.b.g) and Trypanosomabruceirhodesiense (T.b.r.). T.b.g causes over $98 \%$ of reported cases. Both are usually transmitted by the bite of an infected tsetse fly and are most common in rural areas. The disease occurs regularly in some regions of sub-Saharan Africa with the population at risk being about 70 million in 36 countries Simarro et al., (2013). As of 2010 it caused around 9,000 deaths per year, down from 34,000 in 1990 Lozano et al., (2012).

An estimated 30,000 people are currently infected with 7000 new infections in 2012.More than $80 \%$ of these cases are in the Democratic Republic of the Congo. Three major outbreaks have occurred in recent history: 
one from 1896 to 1906 primarily in Uganda and the Congo Basin and two in 1920 and 1970 in several African countries. Other animals, such as cows, may carry the disease and become infected.

Nigeria is ranked amongst the least in Africa in the number of notified Human African Trypanosomiasis (HAT) cases, despite its weak surveillance system for HAT Kennedy, et al., (2013) and WHO 2014. However, the true epidemiological situation in the country is unknown due to the lack of continuity in the surveillance activities as well as political will, ongoing since 1960s, which has limited the number of functional mobile teams for control activities. Although the Delta State had not been known to be endemic for sleeping sickness, this affected both follow-up and case-finding activities in the country Kennedy et al., (2013).

\section{MATERIALS AND METHODS}

\section{Study area}

\section{Delta State Nigeria}

Delta state is an oil and agricultural producing State of Nigeria, situated in the region known as the Delta state, is in the South-South geo-political zone with a population of 4,098,291 (males: 2,674,306; females: 2,024,085) Airauhi et al., (2001). The State presently covers a landmass of about $18,050 \mathrm{Km} 2$ of which more than $60 \%$ is land. The 2006 population figures, obtained from National Population Censors, indicated that Ukwuani had 321,182 inhabitants, Ethiope East 120,390 and Abraka 200,792. The State lies approximately between Longitude 500 and $6^{\circ} .45^{\prime}$ East and Latitude 500 and $6^{\circ} .30^{\prime}$ North. It is bounded in the North and West by Edo State, the East by Anambra, Imo, and Rivers States, South-East by Bayelsa State, and on the Southern flank is the Bight of Benin which covers about 160kilometres of the State's coastline. Delta State is generally low-lying without remarkable hills. The State has a wide coastal belt interlace with rivulets and streams, which form part of the Niger-Delta Osue et al., (2008).

Delta State is ethnically diverse with peoples and numerous languages spoken in the State. The State is divided into 2 main groups based on historical relations, culture and language. The first group is the Igbo subgroup of Delta North Senatorial district sometimes collectively referred to as Anioma. This group has a historical affiliation with the Igbos of Eastern Nigeria, although some parts of it are more Igbo than others.

For instance the Oshimili due to its nexus to the river Niger is linguistically and culturally more Igbo than Ika which has been heavily influenced by the Benin kingdom. The second group comprising Urhobo, Itsekiri, ljaw and
Isoko ethnic groups are collectively referred to as the Delta people.

These ethnic groups occupy the Central and South Senatorial districts of the State. They speak different languages but have a loosely related culture as they traded and intermarried for centuries before colonization. Most inhabitants of the State practice Christianity and very few traditional faiths (2006 Population Census).

There are various solid mineral deposits within the State - industrial clay, silica, lignite, kaolin, tar sand, decorative rocks, limestone, etc. These are raw materials for industries such as brick making, ceramics, bottle manufacturing, glass manufacturing, chemical/insulators production, chalk manufacturing and sanitary wares, decorative stone cutting and quarrying (Osue et al., 2008).

\section{METHODS}

In October 2012, a seroparasitological survey was carried out in 26 villages in the two LGAs namely Abraka and Ethiope East. (Figure 2). Most villages were on the bank of river Ethope, with high risk of man-fly-contact, hence were considered as new endemic foci: there were historical accounts of the disease, recent reports of a case, but presence of the vector could not be demonstrated. All villages with identified suspected cases of HAT were considered for the screening/titration Edeghere et al., 1998.

Human subjects that presented themselves were registered and screened using a Card Agglutination Trypanosomiasis Test (CATT), on fresh undiluted blood Chappuis et al., (2006). Parasitological examinations were then done sequentially on all CATT-positive individuals until the parasite was detected. If individuals had enlarged glands, lymph node fluid was aspirated and examined first.

If enlarged glands were not present, or if examination of the lymph node fluid did not demonstrate the presence of the parasite, the haematocrit centrifugation technique (HCT) was used to detect the parasite in the bloodstream. If the blood sample still tested negative for the parasite after the centrifugation test, an additional blood examination was carried out, using the mini-anion exchange centrifugation technique. All cases positive for the parasite were treatedEdeghere, et al., (1989) and Alhassan, et al., (1998).

A twofold serum serial dilution in CATT buffer was systematically performed on CATT-positive, but parasitenegative individuals. Individuals with a negative antibody end titre below 1-in-4were considered free of infection and were not followed up (WHO, 1998).

Infection was suspected in those with positive antibody end titre of 1 -in- 4 or 1 -in- 8 , and strongly 
012 Int. Res. J. Microbiol.

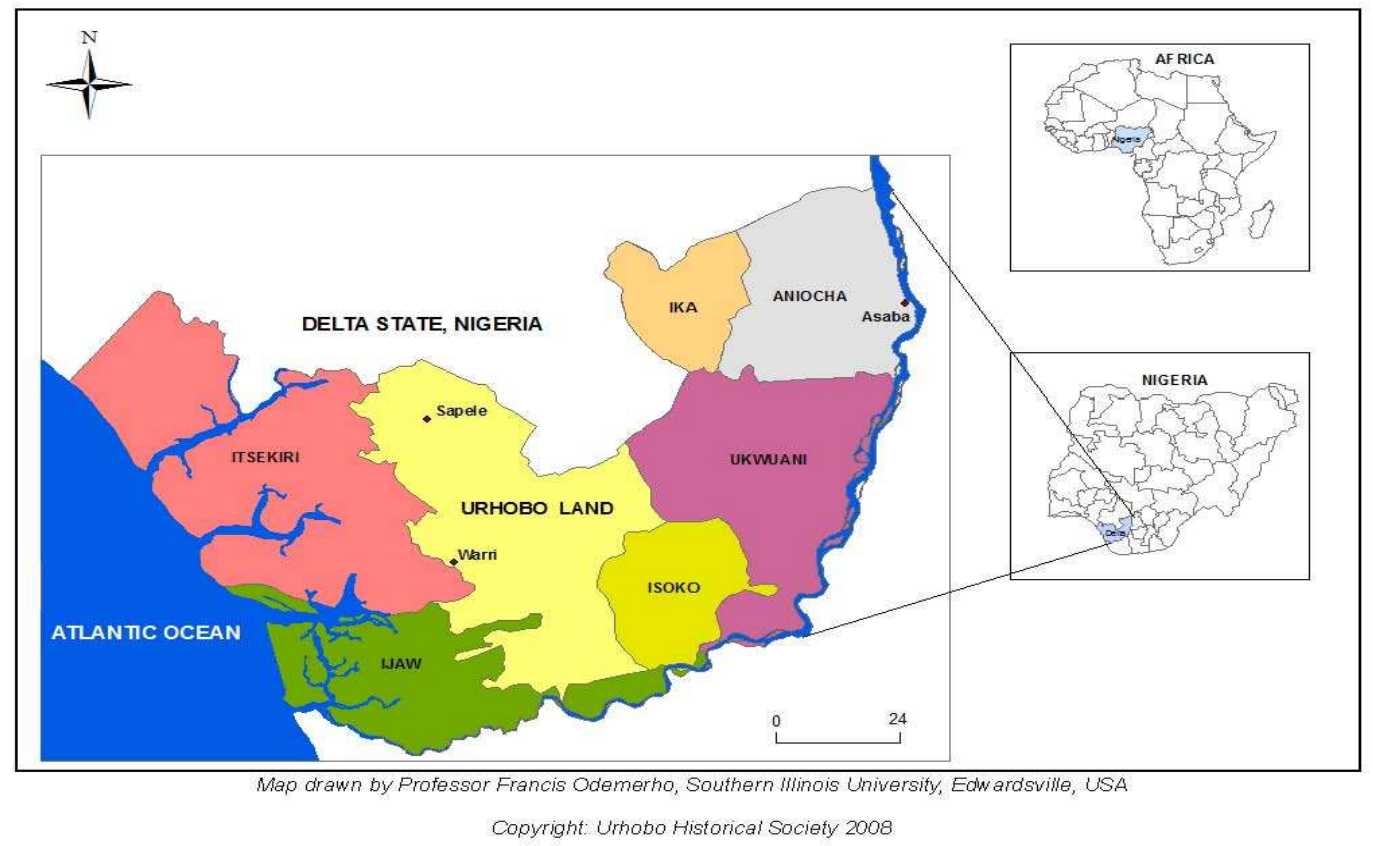

Figure1: A map of Delta State, Nigeria showing Urhobo and other ethnic nationalities

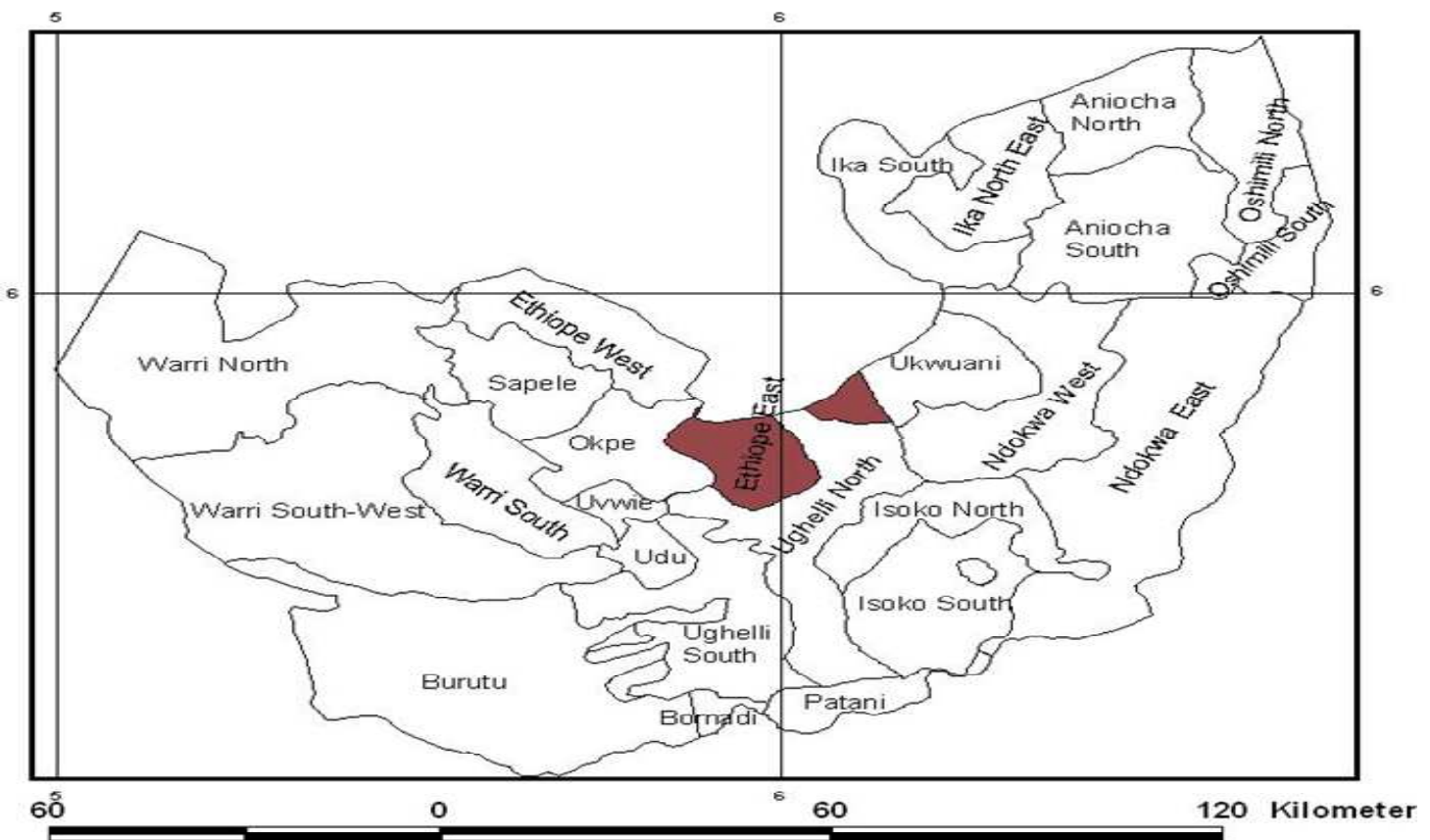

Figure 2: A seroparasitological survey in 26 villages in the two LGAs namely Abraka and Ethiope East.

suspected in those with positive antibody end titre above 1 -in-8. Those with suspected or high titer were screened for other diseases (HIV, Hepatitis, and Malaria) WHO, 2006. No suspected cases were followed up. 


\section{Study design algorithm}

Meeting with the community leaders to explain the screening exercise

Mass mobilization of members of the communities for effective screening

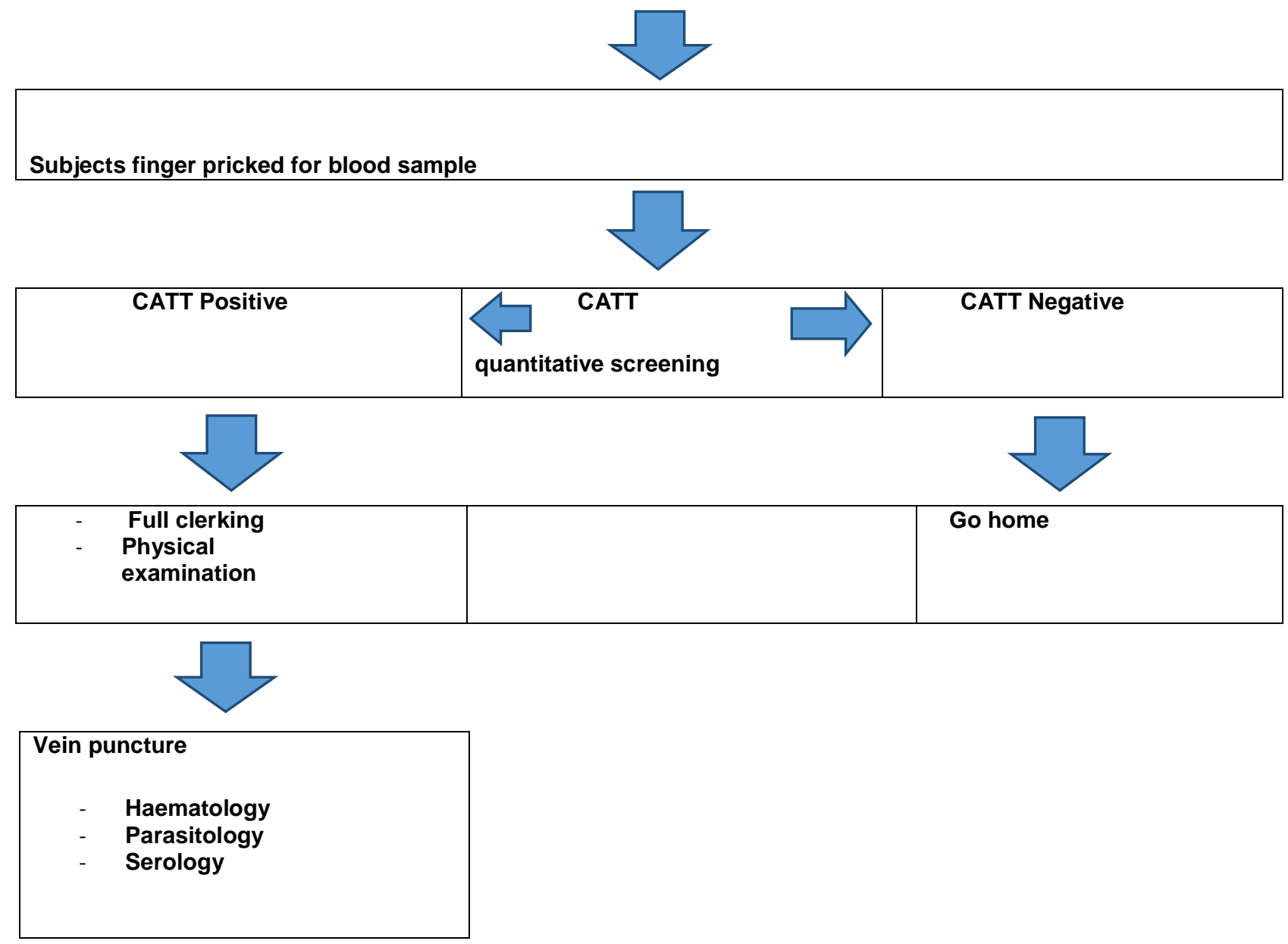

\section{RESULTS}

In 2012, we screened 1,979 people of which 10, 285 people were from the 26 villages in the Ukuwani and Ethiope East LGAs of Delta State. The incidence rate was $0.62 \%$ for the study and more people turned out for the screening in Ukuwani $(1.08 \%$ than Ethiope East $(0.34 \%)(p<0.05)$. CATT positive individuals were $11(0.56 \%)$ out of 1979 screened, consisting of $7(0.57 \%)$ out of 1220 females and $4(0.53 \%)$ out of 759 males (Table 1) with no difference in sex- specific incidences. The positive cases occurred in Umutu and Umuebu communities in Ukuwani LGA, and in Ovu and Okpara inland communities in Ethiope- East LGA.

All cases with tires $>1 / 32$ were followed up using diagnostic algorithms of Chappuiset al., (2005): that is, parasitical examination of peripheral blood, cervical lymph node aspirates and CSF. There was no positive parasitaemia in this survey.

Fever, malaise, headache, cervical lymphadenopathy, facial edema, rashes, somnolence, insomnia, tremor, sexual dysfunction, depression, weight loss, pruritus and pallor were observed amongst the CATT positive patients. Also observed in the patients were anaemia 
014 Int. Res. J. Microbiol.

Table 1: Incidence of CATT positive individuals in Delta State, Nigeria

\begin{tabular}{llllll}
\hline LGA & Estimated Population & Number Screened & Response Rate (\%) & \multicolumn{2}{c}{ CATT Positive } \\
\cline { 5 - 6 } & & & & Number Percentage \\
\hline Ukwuani & 129,390 & 1,297 & 1.08 & 7 & 0.54 \\
Ethiope East & 200,792 & 682 & 0.34 & 4 & 0.59 \\
\hline Total & 321,182 & 1,979 & 0.62 & 11 & 0.56 \\
\hline
\end{tabular}

Table 2: Clinic - pathological parameters of sero - positive individuals with aparasitaemic Human Trypanosomiasis

\begin{tabular}{|c|c|c|c|c|c|c|c|c|c|c|c|c|}
\hline \multirow[b]{2}{*}{ Parameters } & \multicolumn{8}{|c|}{ CATT positive individuals } & \multirow[b]{2}{*}{9} & \multirow[b]{2}{*}{10} & \multirow[b]{2}{*}{11} & \multirow{2}{*}{$\begin{array}{c}\text { Reference } \\
\text { interval }\end{array}$} \\
\hline & 1 & 2 & 3 & 4 & 5 & 6 & 7 & 8 & & & & \\
\hline CATT titre & $128 \uparrow$ & 16 & 16 & $128 \uparrow$ & 16 & 16 & 64个 & 16 & $32 \uparrow$ & $128 \uparrow$ & $64 \uparrow$ & $<32$ \\
\hline Temperature $(* \mathrm{C})$ & 36.8 & 36.9 & 36.5 & 37.6 & 36.5 & 37.5 & 36.0 & 37.5 & 36.8 & 36.2 & $35.8 \downarrow$ & $36.2-37.2$ \\
\hline Weight (Kg) & 50 & 59 & 45 & 45 & 54 & 61 & 64 & 51 & 74 & 46 & 56 & \\
\hline Height (M) & 1.60 & 1.64 & 1.55 & 1.59 & 1.82 & 1.55 & 1.71 & 1.55 & 1.75 & 1.79 & 1.63 & \\
\hline $\mathrm{BMI}(\mathrm{Kg} / \mathrm{m} 2)$ & 19.53 & 21.93 & 19.15 & $17.08 \downarrow$ & $16.30 \downarrow$ & 25.39 & 921.89 & 21.23 & 24.161 & 18.20 & 21.08 & 18.524 .9 \\
\hline PCV (\%) & 36 & 41 & 39 & 37 & 42 & $28 \downarrow$ & $32 \downarrow$ & $31 \downarrow$ & 48 & 36 & 33 & $33.0-45.0$ \\
\hline ESR $(\mathrm{mm} / \mathrm{hr})$ & $45 \uparrow$ & $20 \uparrow$ & $53 \uparrow$ & 2 & $90 \uparrow$ & $49 \uparrow$ & 5 & $80 \uparrow$ & $68 \uparrow$ & 5 & 55个 & $0-10$ \\
\hline MP & + & + & + & + & + & + & + & + & + & + & + & \\
\hline HIV & - & - & - & - & + & - & - & - & - & - & - & \\
\hline HBSAg & - & - & - & - & - & - & - & + & - & - & + & \\
\hline $\mathrm{HCV}$ & - & - & - & - & - & - & - & - & - & - & - & \\
\hline Urea (mmol/l) & 6.5 & 2.3 & 6.2 & $10.0 \uparrow$ & $12.0 \uparrow$ & 3.0 & $14.0 \uparrow$ & 8.2 & 4.3 & 6.5 & 4.5 & $2.5-6.5$ \\
\hline Creatinine (umol/l) & $150 \uparrow$ & 90 & 104 & 145个 & 120 & 100 & 122 & $160 \uparrow$ & $132 \uparrow$ & 106 & 135个 & $9-124$ \\
\hline
\end{tabular}

(63\%), high ESR (80\%), weight loss (19\%), fever $(30 \%)$, HBV $(30 \%)$, HIV (10\%), and renal failure (48\%).

\section{DISCUSSION}

This mass survey, of HAT in Ukwanni and Ethiope East, delta state, Nigeria was carried out in collaboration with
WHO, FMoH, NITR and Delta State Ministry of Health using the CATT Kit for serological screening. The studied area is the most recent endemic for HAT compared to the Northern Nigeria as reported by Edeghere (1999) and Francis (1972) and Olowe (1975).

There was no pathological positive cases of the disease from this surveywhile, in the past both passive and active survey in the recent past in this area (Airauhi 


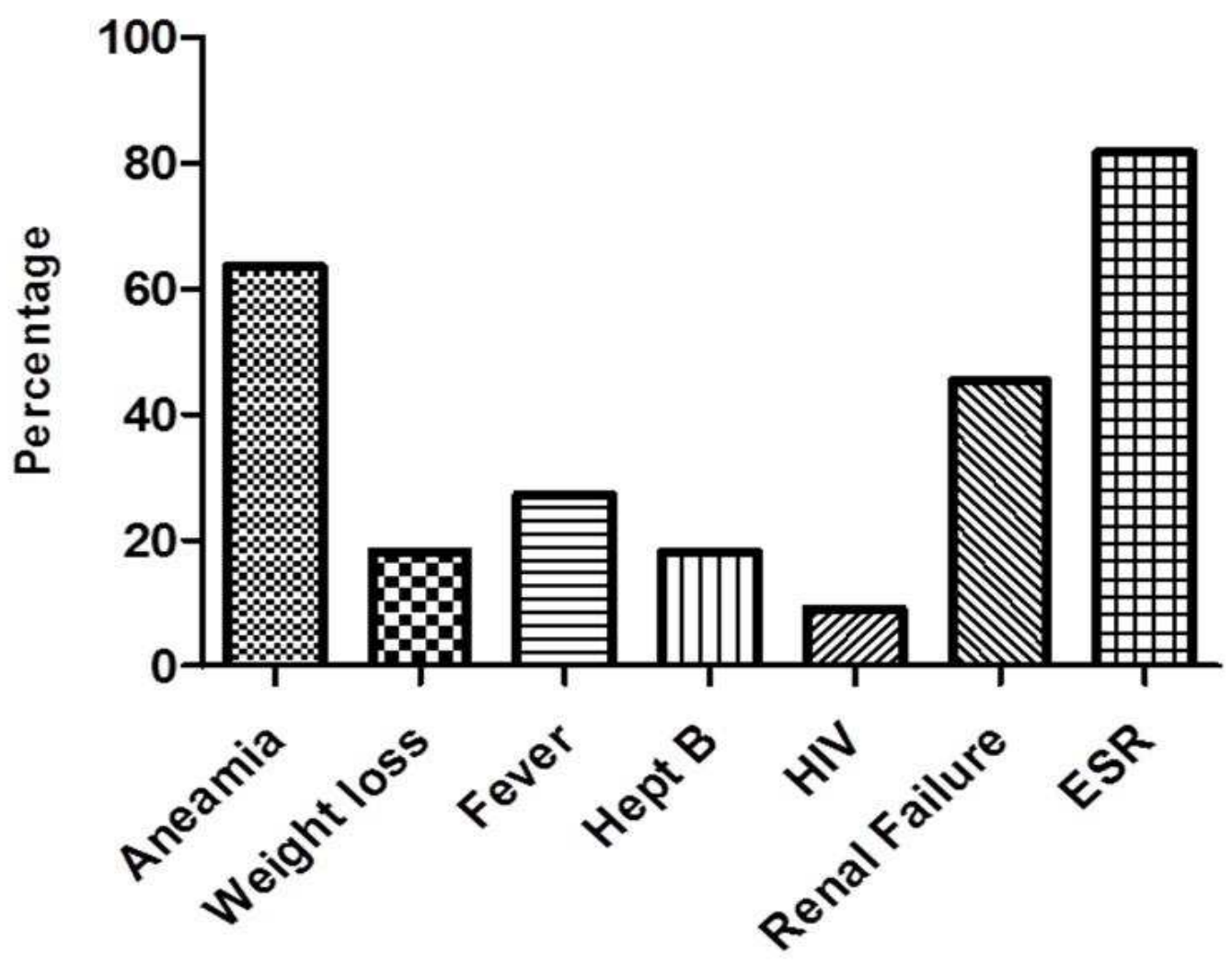

et al., 2000) shows that the risk of infection (3.2\%) of a family is determined by type of occupation i.e. farming and source of water ("Delta State: The Finger of God" 2014-12-28.). Thus, once a member of the family is infected the chances are higher for other family members in the past as suggested by the CATT sensitivity in this survey (8.7\%), Osue et al., (2008).

The response rate for CATT positive for this survey was $1.08(54 \%)$ and $0.34(59 \%)$ for Ukwuani and Ethiope East respectively, which could be an indication of the past infection that had undergone treatment and cured. The CATT positive cases $(>1 / 32)$ could be attributed to cross - reactivity to pregnancy and other parasitic disease (Osue et al., 2008). For this survey malaria, viral hepatitis and HIV were seen as having positive cross reactivity. T. bruceirhodesiense sleeping sickness is an immuno-suppressive disease whose patients have shown a higher affinity to HIV type 2 infections more common in central and western Africa. Such patients when treated, appear to recover from HAT but later succumb to fullblown AIDS. It is recommended that CD4+ $\mathrm{T}$ cell numbers and CD4/CD8 $T$ cell ratios be assessed toinvestigate response to treatment in HIV positive HAT patients (Matete et al., 2005).

The overall prevalence of HIV, hepatitis B, hepatitis C and Human African Trypanosomiasis for this study was respectively $9.1 \%, 18.2 \%, 0.0 \%$ and $63.63 \%$ compare to $3.2 \%, 1.9 \%, 1.6 \%$, and $1.3 \%$ by (Ndilu, et al.,
2016). Alcohol intake, casual unprotected sex, not using condoms during casual sex, sex after alcohol intake and seroprevalence of Human African Trypanosomiasis were significantly associated with a positive HIV test result ( $\mathrm{p}<0.05)$. In this study, sexual risk behaviors were the major risk factors associated with positive HIV tests in blood donors living in Kikwit. It is important to raise awareness about HIV and voluntary blood donation in response to some observations noted in this study such as the low educational level of the blood donors, the low level of knowledge of HIV prevention methods.

For this survey a serum dilution $(>1 / 32)$ was considered positive compared $(1 / 16)$ reported by Osueet al (2005). All CATT positive cases were subjected to titration $\geq 1 / 32(n=11)$ as shown in table I and II. Lumbar puncture was not performed during this survey as there were no parasitological positive cases from our peripheral blood examination. We were however cautious in the interpretation of CATT sensitivity as it has been reported to be less sensitive (Truc et al., 2002 and Lejon et al., 2003). However, this is dependent on the geographical region which is lower in Ethiope East focus in Nigeria (Fever, et al., 2004) compared to what is obtained elsewhere (Pansaerts et al.,1998).

During this survey participants had both practical and the use of CATT kits and reagents. At the end of the survey the CATT kits were exhausted and for further continuation of the survey, WHO is expected to supply 
more CATT kits to NITR through the FMoH to facilitate both passive and active case detection in other parts of the country.

Most $(>90 \%)$ of the Trypanosomiasis cases detected in the area from 1999 to 2000 were diagnosed by the mobile team, and the majority of the cases suspected were not staged (Elhassan,et al., 1997 and Chappuis, et al., 2008). In this study, we were not able to stage the suspected cases as the survey is still on going.

The study area is a relatively active for HAT (Francis, et al., 1972; Okiwe,et al., 1975). The effects of significant titer that is responsive to clinical drug treatment as reported by Isaac et al.,(2010) is an indication that proper survey of the creeks and the tributaries of River Ethiope is likely to reveal some endemic foci.

It was observed that $27.27 \%$ of the CATT positive patient hat a high urea while, $36.36 \%$ had a high creatinine clearance indicating a high risk of association with kidney disease this is however contrary to another study in central Uganda by Magmbo, et al., 2017 where there was no evidence of association but similar to an earlier study by the same author in another location in Uganda (Iganda district of Busoga).

These findings could be explained difference in ethnicity and infection history and also the mechanisms underlying HAT infection outcome and virulence are complex and might differ between populations, and likely involve several host, parasite or even environmental factors (Genovese, et al., 2010). As observed in this study.

\section{Impact of control activities observed in the field}

Where possible, all villages considered endemic in 1997 were subsequently screened in 1998 and in 1999. In July 1999, three villages could not be accessed for security reasons. Between 1997 and 1999, the overall HAT prevalence dropped by $83.3 \%$, from an initial rate of $1.97 \%$ in 1997 , to $0.55 \%$ in 1998 , and to $0.33 \%$ in 1999 . During this same period, the screening rate dropped from $94.3 \%$ in 1997 , to $75.4 \%$ in 1998 , and $70 \%$ in 1999 , due to lack of interest by the population (WHO fact sheets. Revised August 2006; Fact sheet 259).

\section{Impact of control activities on the Eku Baptist Hospital and the National Sleeping Sickness Centre Gboko Benue State}

The impact of the control activities in the Eku Baptist hospital could also be observed, where people from area surveyed used to seek treatment. However the National Sleeping Sickness Centre Gboko has had little impact because of low index of suspicion of Sleeping Sickness amongst medical experts and the lack of political will on the part of the Federal Government since 1960s.

\section{ACKNOWLEDGEMENTS}

We thank Delta State Ministry of Health, Federal ministry of Health, W.H.O and PATTEC for their collaboration and financial supports. This project was financed partly by W.H.O, PATTEC and FMOH.

\section{REFERENCES}

Airauhi LU, Ibadin MO, Omoigberale AI, Okaaka CE, Halim NKD (2001). HAT in rain forest of Nigeria: experience from 3 village communities of Delta State. The Nigerian Medical J. 39(3):71-75.

Chappuis F, Loutan L, Simmaro P, Lejon V, Buscher P (2005). Options for field diagnosis of HAT. Clinical Microbiology Review 18(1):133146

Control and surveillance of African trypanosomiasis. Geneva (1998). World Health Organization; Technical Report Series No. 881. Delta State: The Finger of God". Retrieved 2014-12-28.

Edeghere H, Olise PO, Olatunde DS (1989). HAT (sleeping sickness): new endemic foci in Bendel State, Nigeria. Tropical medicine and parasitology. 40: 16-20

Elhassan EO, Sanda EA, Ikenga MA, Ukah JCA (1997). Studies on the prevalence of sleeping sickness in Ethiope East Local Government Area of Deltal State, Nigeria. In annual Report, Nigerian institute for Trypanosomiasis Res. 1997-1998

Elrayah EL, Rhaman MA, Karamala LT, Buisher KKM (2007). Evaluation of the serodiagnostic tests for T.bgambiense Human African trypanosomiasisin southern Sudan. East Meditarean Health J. 13:5

Federal Republic of Nigeria, National Bureau of Statistics (2006). Population Census. Archived from the original on 2009-03-25.

Fèvre EM, Coleman PG, Welburn SC, Maudlin I, (2004). "Reanalyzing the 1900-1920 sleeping sickness epidemic in Uganda". Emerging Infect. Dis. 10 (4): 567-73.

Fevre FM, Wissmann BV, Wilburn SC, Lutumba P (2008). The burden of Human African Trypanosomiasis. Plos Neglected Tropical Disease J.; 2: e 333.

Francis TI (1972). Visceral complications of Trypanosomagambiense in a Nigerian. Proceeding of First Medical Research Meeting, Yaba, Lagos 190-191

Genovese G, Friedman DJ, Ross MD, Lecordier L, Uzureau P (2010) Association of trypanolytic ApoL1 variants with kidney disease in African Americans. Sci. 329: 841-845. pmid:20647424

Kennedy PG (Feb 2013). "Clinical features, diagnosis, and treatment of human African Trypanosomiasis (sleeping sickness). Lancet neurology 12 (2): 186-94.

Lozano R (2012). "Global and regional mortality from 235 causes of death for 20 age groups in 1990 and 2010: a systematic analysis for the Global Burden of Disease Study 2010". Lancet 380 (9859): 2095-128.

Magambo PK, Harry $N$, Julius $M$, John $E$, Vincent $P$, Issa $A$, Dieuodonne S, Christiane M, Annette HM, Özlem TB, Enock M for the TrypanoGEN Res. Group, as members of The H3Africa Consortium.

Matete GO, Kajejo OA (2005). Human African trypanosomiasis and human immune deficiency virus co-infection in Western Kenya. East African Med.J.82(1):20-3.

Media centre (2014). "Fact sheet N259: Trypanosomi asis, Human African (sleeping sickness)". World Health Organization. Retrieved 25 April 2014.

Ndilu L, Ekila M, Mayuma D (2016). Characteristics, behaviors and association between Human African Trypanosomiasis and HIV seropositivity among volunteer blood donors in a semi-rural area: A survey from Kikwit, the Democratic Republic of Congo. Acta Parasitologica, 61(4), pp. 689-693.

Osue Ho, Lawani Fag, Saddiq L, Aderemi A, Diara A, Lejon V, Simmaro P (2008). Active transmission of Trypanosomabruceigambiense Dutton, 1902 sleeping sickness in Abraka, Delta State, 
Nigeria. Sci. World J. Vol 3 (NO2). http://www.scienceworldjournal. org/article/viewFile/2811/2105

Pansaerts R, Van Meirvenne N, Magnus E, Verhelst L (1998). Increased sensitivity of the card agglutination test CATT/Trypanosomabruceigambiense by inhibition of complement. ActaTropica; 70:349-54.
Population Census, Federal Republic of Nigeria, National Bureau of Statistics (2006). Archived from the original on 2009-03-25.

Ruiz AJ, Simaro PP, Josenando T (2002). Control of Human African Trypanosomiasis in Quicama focus Angola. Bull WHO; 80 - 9 . 